\title{
SOCIO-DEMOGRAPHIC POTENTIAL OF HUMAN RESOURCES IN THE VISEGRAD REGIONS
}

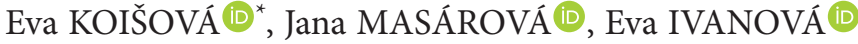 \\ Department of Economics and Economy, Faculty of Social and Economic Relations, \\ Alexander Dubček University of Trenčín, Trenčín, Slovakia
}

Received 16 January 2020; accepted 28 January 2021

\begin{abstract}
Human resources are the key factor in the development of countries and regions. They affect the prosperity and competitiveness of the countries and regions. The purpose of the study was to assess the human resource potential in the $\mathrm{V} 4$ countries and to identify the groups of regions that share similar socio-demographic characteristics. Changes in these characteristics were tracked in the years of 2000, 2008, 2016 at the NUTS II level. Hierarchical cluster analysis was utilised as the main research method in order to identify the groups of regions where measures need to be taken to maintain regional development. We found out that the best conditions for the potential of human resources are concentrated mainly in metropolitan areas. On the other hand, there are regions that do not make sufficient use of their potential in the area of human resources development, e.g. the region of Východné Slovensko. It is the region with future prospects of human resource potential In the future it is necessary to remove shortcomings and low human resources potential in lowperforming regions.
\end{abstract}

Keywords: human resources, regional development, regional disparities, Visegrad Group, demographic indicators, social indicators, labour market.

JEL Classification: O15, J24, O18, R23.

\section{Introduction}

Human resources and their potential are vital for economic and social development of economies and their regions as they can make a considerable impact on their macroeconomic performance. Habánik et al. (2019) claim that there are several factors that affect economic growth of countries, such as trends in the development of demographic, political, legislative, cultural, commercial, and natural conditions. These general factors and trends drive the development in the V4 countries and their regions, too. The V4 countries exhibit fairly large disparities in economic and social development, and thus in their regional economic

\footnotetext{
${ }^{\star}$ Corresponding author. E-mail: eva.koisova@tnuni.sk
} 
performance. They, according to Mariš (2014), may also exist due to spatial relations among the regions as they affect the location of production factors. The data on regional development serve to prompt development impulses to the lagging regions. There are several barriers to the development of the EU regions, such as imperfect mobility of factors of production, goods and information as well as barriers associated with demographic trends.

In this regard, it is important to select the right indicators or the set of indicators to measure and evaluate regional and spatial structure, its changes and development (Hamada \& Kasagranda, 2014). First, gross domestic product (GDP) is used to compare the regional competitive performance. It is also the key indicator when the decisions on the eligibility of drawing the EU financial resources for regional development are made. Regional development, however, is not determined by economic indicators alone. GDP creation will not do without human resources that are critical for both social and economic development. Vojtovic and Krajnakova (2013), however, claim that it can be assumed that economic development and labour market trends do not reflect directly the pace of economic development and do not show the causal relationship between the economic growth and unemployment rates in a comprehensive manner. Recently, many European countries, including the V4 countries, have been facing worrisome demographic and social trends, which will sooner or later trigger an economic slowdown. The Visegrad Group is a grouping of four Central European countries engaged in non-institutionalized cross-border cooperation. Thus, the grouping has no institutionalized structures (Valuch et al., 2011). The V4 are the neighbouring countries linked due to geographic proximity (Klus, 2015). They, however, have not been characterized by historical, cultural and economic proximity (Kuźnar, 2018). Visegrad countries had to change from a system of planned economies to free-market economies at a similar time, and at the same time, they joined the European Union (Bieszk-Stolorz \& Dmytrów, 2020). The V4 was not created as an alternative to the Pan-European integration efforts, nor does it try to compete with the existing European structures. On the contrary, the Group aims at encouraging cooperation with all countries and other regional groupings (Visegrad Group, 2016). If counted as a single nation state, the V4 would be the fifth largest economy in Europe and twelfth globally (Hahn, 2013).

The purpose of the study was to assess the human resource potential in the V4 countries and to identify the groups of regions that share similar socio-demographic characteristics. In addition, the development of socio-demographic characteristics was tracked in 2000, 2008 and 2016. Hierarchical cluster analysis was employed as the primary research method to identify the groups of regions in which similar measures can be implemented in order to sustain regional development. Based on the research results, several measures that could contribute to the development of human potential in the regions were put forward.

The paper is organized into several sections. The first section addresses the theoretical background related to the issue of human resources and their potential. The second section provides information on the research methods, research design and data sources. In the third section, the conditions for the human capital development in the V4 regions in 2000, 2008 and 2016 are evaluated. The concluding section summarizes the key findings and provides suggestions for decision makers. 


\section{Theoretical framework}

Economic development is closely linked to human resources (Diebolt \& Hippe, 2019; Novikov et al., 2020). The quality and development of human resources depend not only on the organizations they work for but also on the state as the creator of conditions for sustainable economic development (Mihalčová et al., 2007). Zurn et al. (2004) maintain that economic, sociodemographic, cultural and geographical factors contribute directly or indirectly to shaping and transforming the entire society and hence the workforce. The economic and social development of economic units goes hand in hand with the development of regions and human potential. Economic growth is a multidimensional process, and a part of a clear connection between the size of population, capital resources, investment or technical progress (Bolińska et al., 2019).

Majerová (2019) maintains that differences in the level of the socio-economic indicators should be maintained within sustainable limits for the sake of the welfare of the country as a whole. The analysis of these indicators may serve as the basis for development policy on the regional level. Regional development is a holistic process aimed at achieving progress in economic, social, cultural and environmental areas. In terms of social and economic conditions, regional development relies on the potential of regions in the areas of human resources and employment, research and innovation capability, business sphere and institutional arrangements, competencies and resource allocation, infrastructure, etc. The quality of human resources is affected by the development of the human capital which depends on such directions of a state policy as improvement of education systems, increases in the income of the population, optimization of migration policy, improvement of social and economic infrastructure, development of social partnership and initiatives of the enterprise, support of development of civil society (Tchanturia et al., 2015). Human capital raises the standard and quality of life of people. It is especially true when investment is made in intellectual activities promoting education (Sahadev \& Demirbag, 2011; Karamessini, 2008), health, researchrelated knowledge acquisition and dissemination (Blažej, 2004), ICT, citizens' safety, business and economic freedom as well as culture, art and other components of economic and social life (Tchanturia et al., 2015). The development of human capital is also promoted by the development of digital technologies, which are already transforming the essential social services, such as education and health care and how people interact with their governments (Chaaben \& Mansouri, 2017). In the modern information society, people play an increasingly important role (Novikov et al., 2020). Promotion and use of digital technologies creates previously inaccessible opportunities for improving the organization of work processes, increasing productivity rates and labour efficiency, which naturally leads to the fact that human capital in all its dimensions starts to act as the most important value of the society (Ivanova \& Zaretsky, 2019). Digitalisation of the economy has both positive (creation of new jobs and occupations, development of human resources) and negative effects on the labour market (shortage of highly qualified personnel with digital skills, job cuts) (Astafurova et al., 2019). Digital technologies as well as digital services change the rules of employment and the requirements of competences, knowledge, skills and attitudes of employees (Chinoracký \& Čorejová, 2019). Digitalisation accelerates the transformations of the labour market and 
accentuates the flexibility in the form of individually tailored temporary work and service contracts, freelance work and multiple jobs (Vasilescu et al., 2020). The impact of digitalisation on the labour market is addressed by several authors (e.g. Larsson \& Teigland, 2020; Martinák, 2020; Mayerová \& Hyžová, 2019 and others).

Regional development experts agree that human resources are the key to the development of countries and regions (Gennaioli et al., 2013; Liptáková, 2007). Human resources set the production resources in motion, determine their use and impact the resulting output (Naydenov, 2019). Thus, human resources are the key player in the further development and economic growth. Moreover, they affect the prosperity and competitiveness of the countries, regions and enterprises (Akócsi et al., 2012; Diebolt \& Hippe, 2019; Lelek, 2014). Likewise, Vilinová and Repaská (2018) claim that human resources are an irreplaceable part of the socio-economic potential of regional development. In the region, human resources are applied as a carrier of socioeconomic activities, which are performed in the area, and they influence and transform it, but at the same time, the area relationships and connections influence the effectivity of the economic activity.

Concerning this, it is important to track the existing circumstances and their changes or to monitor inequalities in the distribution of population and its demographic and social characteristics being the major constraints of regional development. This view also supported by Kasanická and Czaková (2009) who hold that population dynamics is one of the most important factors affecting the long-term regional sustainability. Therefore, it is necessary to track its components (natality, mortality, immigration, emigration) since all of them reflect certain trends in the development of regions. Grmanová et al. (2018) maintain that a balanced demography and population structure are essential for any economy to thrive. In terms of the research of demographic factors in human resources, the following indicators are mainly examined: population, migration, population age structure, educational structure of population, employment, social structure and social integration, etc. (Hübelová, 2014; Vilinová \& Repaská, 2018). With regard to reproductive behaviour, fertility, mortality and abortion rate are looked at. Currently, the trends of aging population and its serious socio-economic implications are closely watched and analysed. Population aging alters the structure of population and its age composition with an increasing share of elderly people aged 85 and above. For the purposes of measuring the quality of human resources, the indicator of educational attainment is used. Lelek (2014) notes that the share of people having completed tertiary education is of particular significance for the development of countries and regions. The data on educational attainment are often used as the indicator of human capital and individual level of competence. They describe the levels of skills associated with particular levels of education, which are available in both the population and the labour market (Bobáková, 2018). Qualified people are expected to contribute with their activities and knowledge to sustainable development. Ulewicz and Blašková (2018) argue that sustainable development requires knowledge management be approached as the element of creating regional competitive advantages.

Demographic changes affect the labour market, too. Tuleja et al. (2006) argue that the demographic structure of population and the labour market rank among the most accurate indicators of the socio- economic situation of populations. Employment rate is a standard 
and widespread indicator of the labour use and labour market functionality. It is expressed as the proportion of employed people in the working age population. Economic policies of all countries attempt to increase employment rate and decrease unemployment rate. High long-term unemployment has also negative implications for labour markets. The situation in labour markets can impact the factors such as income, standard of living of citizens and employers of regions, and can also boost the overall performance of regions. That is why the issue of regional disparities in labour markets has been attractive for many authors, such as Rajčáková and Divinský (1995), Havierniková and Janský (2014). The issue of labour market disparities is addressed by Székely (2001) and Bezák (2001). The labour market situation in the V4 countries was examined by Potužáková (2012), Kotýnková and Kubelková (2012), Klimko (2015), Bakó and Lakatos (2016), Fazekas and Köllõ (2017), Kostrová (2018), Lewandowski and Magda (2018), Duszczyk and Matuszczyk (2018) and many other authors.

In order to evaluate similarities or differences in the human resource potential of the V4 regions, the method of cluster analysis was used. Cluster analysis has been widely used by many researchers. Shubat et al. (2017) used cluster analysis to assess the demographic potential of Russian regions. Zhang and Li (2014) used cluster analysis to identify Chinese provinces and to investigate the qualitative characteristics of the given populations. Lv et al. (2011) examined the clustering of multiple lifestyle risk factors and their association with socio-demographic characteristics. Havierniková et al. (2018) examined the issues of clustering in various fields of industry in Slovakia and Poland. There are big disparities among the regions of the European Union, which widened after the 2004 enlargement. This fact was pointed to by Del Campo et al. (2008) in their research study titled The Socioeconomic Diversity of European Regions. The study aimed to analyse this diversity and to propose a classification of European regions that is adjusted to the different axes of socio-economic development and, simultaneously, is useful for the purposes of European regional policy. Multivariate cluster analysis was also used by Laboutková et al. (2016) who identified relations between the degree of decentralization and economic imbalance. Palevičienè and Dumčiuvienė (2015) claim that an increasing share of EU budget devoted to Regional Policy draws big attention of economists who are analysing the impact of the structural support on economic growth. Some research states, that increasing the size of the structural funds allows the poorer regions to catch up faster with the richer regions (Arcalean et al., 2012).

\section{Methodology}

To assess the human resources potential in the Visegrad Four regions, the following sociodemographic indicators were used: fertility rate, infant mortality rate, median age of population, proportion of population aged 85 years and more, age dependency ratio (population aged $0-14$ and 65 and more to population aged 15-64), tertiary education, employment rate, long-term unemployment rate, income. The data available from 2000 to 2016 for all 35 regions of the Visegrad Four at NUTS 2 level were used in the research. The factor data were taken from the Eurostat database and their sources are listed in Table 1. 
Table 1. Sources of used databases and data

\begin{tabular}{|l|l|l|l|}
\hline \multicolumn{2}{|c|}{ Factor } & \multicolumn{1}{c|}{ Unit } & \multicolumn{1}{|c|}{ Source (Eurostat) } \\
\hline 1. & Median age of population & Year & [demo_r_pjanind2] \\
\hline 2. & Proportion of population aged 85 years and more & Percentage & [demo_r_pjanind2] \\
\hline 3. & Age dependency ratio & Percentage & [demo_r_pjanind2] \\
\hline 4. & Fertility rate & Number & [demo_r_frate2] \\
\hline 5. & Infant mortality rate & Rate & [demo_r_minfind] \\
\hline 6. & $\begin{array}{l}\text { Tertiary education (levels 5-8) } \\
\text { (Population aged 25-64) }\end{array}$ & Percentage & [edat_lfse_04] \\
\hline 7. & Employment rate & Percentage & [lfst_r_lfe2emprt] \\
\hline 8. & Long-term unemployment rate & Percentage & [lfst_r_lfu2ltu] \\
\hline 9. & Income (Income of households) & Euro per inhabitant & [nama_10r_2hhinc] \\
\hline
\end{tabular}

A cluster analysis was employed to assess differences or similarities in the V4 regions. Cluster analysis belongs to multi-dimensional exploration techniques, by which subjects are grouped into groups - clusters - based on their similarities and differences. The clusters are formed in a way to achieve the greatest possible similarity among subjects within a cluster and at the same time to achieve the greatest difference between subjects in different clusters. The method is based on the classification of statistical sample variables into clusters in such a way that the variables belonging to one cluster are very similar from the viewpoint of the characteristics monitored, and the variables belonging to different clusters are significantly different (Stankovičová \& Vojtková, 2007; Řezanková et al., 2007). The distance between the objects is expressed by various ways. One of them is the Euclidean distance (Minarrík et al., 2013). The individual countries were classified into clusters on the basis of the standardized squared Euclidian distance:

$$
D_{N}\left(i ; i^{\prime}\right)=\sqrt{\sum_{j=0}^{p} d_{j}^{2}\left(i ; i^{\prime}\right) / s^{2}\left(x_{j}\right)},
$$

where: $d_{j}\left(i ; i^{\prime}\right)$ is the distance between the $i$-th and $i^{\prime}$-th variable; $i \neq i^{\prime}=1,2, \ldots n$, it means $d_{j}\left(i ; i^{\prime}\right)=x_{i j^{\prime}} x_{i^{\prime} j}, j=1,2, \ldots, p$, and $s^{2}\left(x_{j}\right)$ is a sample variance of $j$-th variable.

Euclidean distance or geometric metric is one of the most used distance metrics. It is probably the most frequently used metric that represents the length of the hypotenuse of a rectangle and its calculation is based on the Pythagorean theorem. It is expressed by the formula

$$
d_{E}\left(x_{k}, x_{l}\right)=\sqrt{\sum_{j=1}^{p}\left(x_{k}-x_{l}\right)^{2}}
$$

and represents the standard type of distance. In the research study, the metric of Euclidean distance is employed as the methods of hierarchic clustering are appropriate for this type of research.

Cluster analysis allows us to use a great number of input data with the only limits being their accessibility and consistency. The output from hierarchical clustering is a dendogram 
that shows the identified clusters of regions (Kožiak et al., 2014). Since the clusters of regions so identified share similarities, it can be deduced they also face similar difficulties and problems that need to be tackled in order to improve their social and demographic characteristics to catch up with better performing regions.

Furthermore, differences in the level of selected indicators in the Visegrad Four regions were looked at. Statistical indicators to monitor the observed phenomenon variability by means of setting the minimum, maximum, average, variation range and variation coefficient were used. To find out how the values in statistics file are similar or different, we determined the variability degree by means of a variation range:

$$
R_{v}=x_{\max }-x_{\min } .
$$

The variation coefficient is used to compare the variability of files with different diameters and is set as:

$$
v_{x}=\frac{s}{\bar{x}}
$$

where $\bar{x}$ - average; s - standard deviation, while the "s" was set as follows:

$$
s=\sqrt{s^{2}}=\sqrt{\frac{\sum_{i=1}^{n}\left(x_{i}-\bar{x}\right)^{2}}{n}} .
$$

A simple arithmetic mean is described by following relationship:

$$
\bar{x}=\frac{1}{n} \sum_{i=1}^{n} x_{i}=\frac{\sum_{i=1}^{n} x_{i}}{n},
$$

where $n$ - the number of observations; $i=1,2,3 \ldots n$.

\section{Results and discussion}

In the paper, similarities and differences of the Visegrad Four regions have been examined and assessed. First, a cluster analysis has been applied to assess similarities of the regions. Next, variability indicators have been used to assess regional differences in the V4 countries.

\subsection{Assessment of similarities across the V4 regions using a cluster analysis}

Cluster analysis allows us to identify the groups of regions that have the best or worst conditions to develop their demographic potential (Shubat et al., 2017). Three years from the time series from 2000 to 2016 were chosen to be analysed.

For the time series was long, three years were selected to monitor changes in the regions and their clustering with changing input factors. The first year analysed was 2000. The first year in the 2000-2016 time series gives a picture of the initial situation in the regions. Before 
2000, Visegrad countries went through difficult times and had to take measures to stabilize economy. In 2000, several effects of the measures adopted could be seen. V4 economies began to stabilize and reached macroeconomic balance. The world economy of 2008 faced a severe global economic downturn which also affected Central Europe and V4 economies, which struggled with its effects. As a result, changes in the market of goods and services as well as socio-demographic changes in the labour market occurred. The last analysed year was 2016. It was the year of growing economic performances in V4 countries which were slowly approaching the performances of the developed countries EU.

First, correlating factors were excluded. Then, the following nine factors were selected and used to perform the cluster analysis: median age of population, proportion of population aged 85 years and more, age dependency ratio (population aged 0-14 and 65 and more to pop. aged 15-64); fertility rate; infant mortality rate; tertiary education; long-term unemployment rate; income; employment. Next, the cluster analysis was performed using the STATISTICA software and regional similarities or differences in clusters were identified. Then, the trends and regrouping of regions into other clusters in the years under analysis were established.

To make the data on the factor development more comprehensible and precise, the development of the maximum and minimum values, variation range, and variation coefficients of the indicators were examined for 2000-2016. The data obtained were used to evaluate the development of regional disparities in the V4 regions. Moreover, similarly developed regions in terms of human resource potential in selected socio-demographic factors were identified. In the concluding section, several measures to decision-makers were proposed.

\subsubsection{Year 2000}

In 2000, the V4 were not the members of the European Union. All four countries aspired to become the members of the European Union, perceiving their integration in the EU as a step forward in the process of their integration, and political and economic orientation towards the values of the European Union. It was not easy for the countries to meet the preaccession criteria as they were the economies which were changing from a centrally planned economy to a market economy. All these facts were reflected in their social and demographic development.

A dendrogram for 2000 (see Figure 1) shows two basic clusters.

The first cluster contains the Polish region of Opolskie and two Hungarian regions of Dél-Alföld and Dél-Dunántúl. Compared to other regions, they are primarily similar in lower employment rates (from $53.1 \%$ to $55.9 \%$ ) and lower incomes. They also share similarities in fertility rate and median age.

Other regions are located in the second big cluster. The second cluster contains four sub-clusters - there are all the metropolitan regions in the right cluster: the Polish region of Mazowieckie, the Czech region of Praha, the Slovak region of Bratislava and the Hungarian region of Közép-Magyarország. They share high employment rate, high salaries (from € 8,900 to $€ 11,200)$ and the high percentage of population with completed tertiary education. On the other hand, these regions show less favourable values in fertility rate, age dependency ratio and high proportion of population aged 85 years and more. 


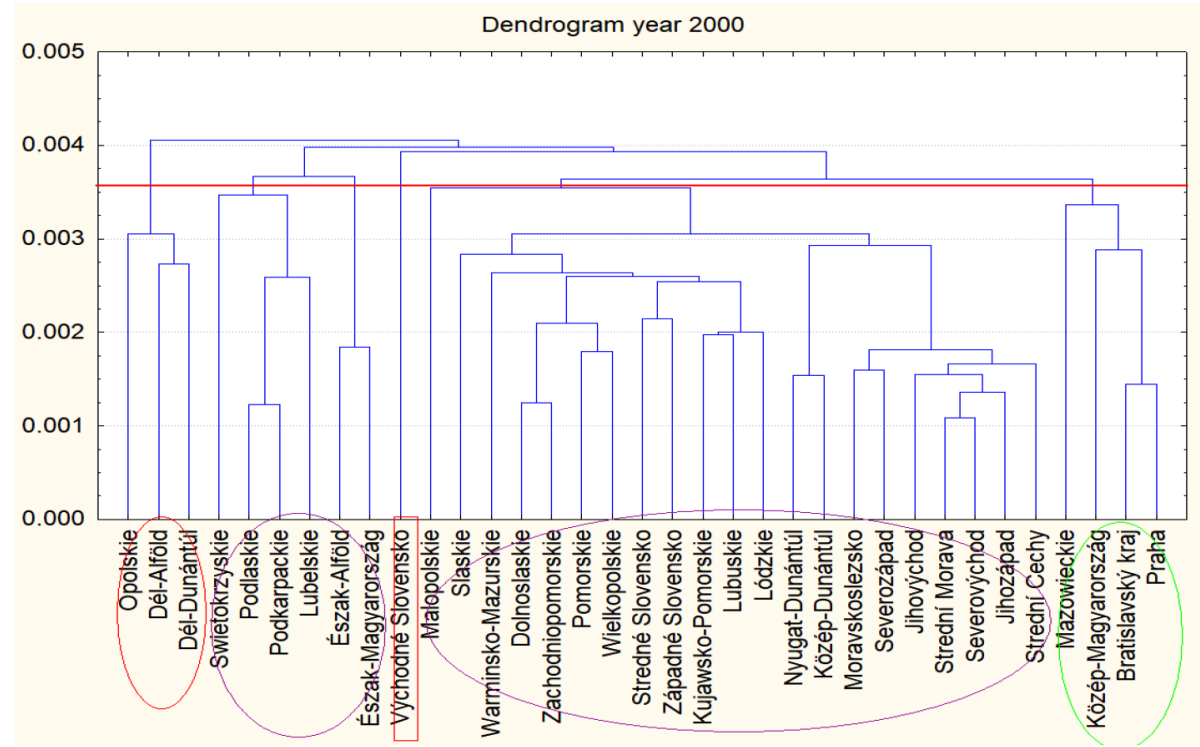

Figure 1. Dendrogram - year 2000

Next to this cluster, there is a cluster containing as many as 21 Visegrad Four regions. The average age of the population in these regions ranges from 33 (Warminsko-Mazurskie) to 38.7 (Nyugat-Dunántúl) and their fertility rates have average values. High infant mortality also poses a problem (e.g. Slaskie 10.1; Nyugat-Dunántúl 10; Dolnoslaskie 9.5).

The third cluster is the stand-alone region of Východné Slovensko with the highest longterm unemployment rate $(14.1 \%)$, the lowest share of population with tertiary education, the highest infant mortality rate, and the lowest values of average age.

The fourth cluster contains four Polish regions of Lubelskie, Podkarpackie, Swietokrzyskie, Podlaskie and two Hungarian regions of Észak-Magyarország and Észak-Alföld. These regions are characterized by low incomes, higher values of long-term unemployment rate, high values of age dependency ratio, and higher values of fertility rate.

\subsubsection{Year 2008}

As a part of the European Union, the Visegrad Group achieved a relatively high economic growth, which was influenced by the positive development of foreign investment. In the second half of 2008, the economic recession began to be felt in the V4, which caused an economic downturn due to their strong connection to Western European countries, in which the crisis caused a significant decline in aggregate demand. Poland was not that negatively affected by the global crisis as the remaining V4 countries (the slowdown in growth only) for its large domestic market and less open economy. The crisis hit Hungary hardest which was also due to high government debt. This situation led to a decline in the employment rate and a rise in the unemployment rate. With regard to socio-demographic factors, the situation was different compared to 2000. The differences are listed in Figure 2. 
The dendrogram shows two basic clusters. Two metropolitan regions of Praha and Bratislava are no longer included in the second big cluster as they formed a separate cluster. Income increased significantly to $€ 17,000$ in region of Praha and $€ 19,300$ in the region of Bratislava. On the other hand, these regions are also similar in the low level of the fertility rate, although there was a slight improvement in this indicator compare to year 2000. There was also similar development in the age dependency ratio and the proportion of population aged 85 years and more. These indicators were almost not changed. All these facts contributed to the cluster creation in which they are two regions with the similar results of the mentioned indicators.

The second cluster contains four sub-clusters with the remaining regions. The first cluster is made up of the Polish region of Mazowieckie and the Hungarian region of Közép-Magyarország. These are the metropolitan regions, which were incorporated in the cluster along with the regions of Praha and Bratislava in the previous dendrogram. Compared to other V4 regions, they share higher incomes, higher percentage of population with tertiary education and better (lower) average ages than the regions of Praha and Bratislava. Age dependency ratio shows higher values even though decreased ones compared to 2000. Both regions recorded identical values in infant mortality despite a marked improvement compared to 2000.

The region of Východné Slovensko formed a separate cluster again. The region has the lowest average age, the lowest proportion of population aged 85 years and more $(0.8 \%)$, and a high fertility rate which can be considered to be the potential for its development. The region also recorded the highest infant mortality rate (9.5\%), high long-term unemployment rate and low incomes. These findings show that this region needs more effective instruments of regional policy when compared to other V4 regions.

The third cluster contains the Hungarian regions of Dél-Alföld, Észak-Alföld, and ÉszakMagyarország that share low average age, high proportion of population aged 85 years and

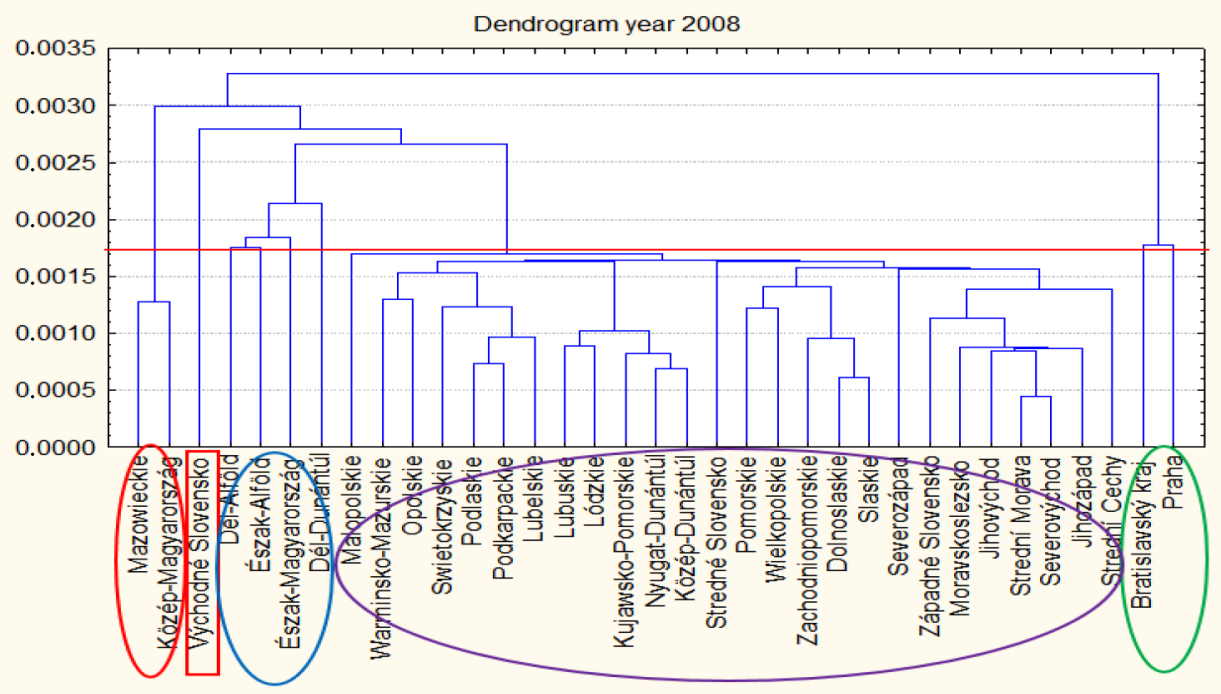

Figure 2. Dendrogram - year 2008 
more, the highest age dependency ratio (from 46.2 to $48.4 \%$ ), lower percentage of people with tertiary education, the lowest employment rate and low incomes.

The fourth cluster is made up of the remaining 26 regions. The average age ranges from 35.4 years (Podkarpackie) to 40.5 years (Dél-Dunántúl) while fertility rate has average values. Compared to 2000, positive values were achieved in tertiary education, long-term unemployment and household incomes in almost all the regions. In this period, the Euclidean distance decreases and so do the disparities among regions.

\subsubsection{Year 2016}

In the post-crisis years, the V4 countries achieved favourable economic development, although their economic growth was slower than before the crisis. There was only a slight rise in the level of prices, and there was even a decline in prices in Slovakia and Poland (deflation). Favourable economic developments led to significant improvements in the labour markets. Employment rates went up, unemployment and long-term unemployment rates decreased (the regions of Stredné a Východné Slovensko showed the highest long-term unemployment rates). In addition, the income level of population went up with a particularly high increase in the region of Bratislava.

There are two main clusters with a reduced distance between each other in the dendrogram for 2016 (Figure 3). The first cluster is comprised of the three metropolitan regions (Czech, Slovak and Polish). The regions share high incomes (mainly the region of Bratislava: $€ 24,000$; region of Praha: $€ 19,500$ and the region of Mazowieckie: $€ 17,800)$. Other similar interregional features include average age, fertility rate, high employment, low long-term unemployment rate and the high share of the population with tertiary education.

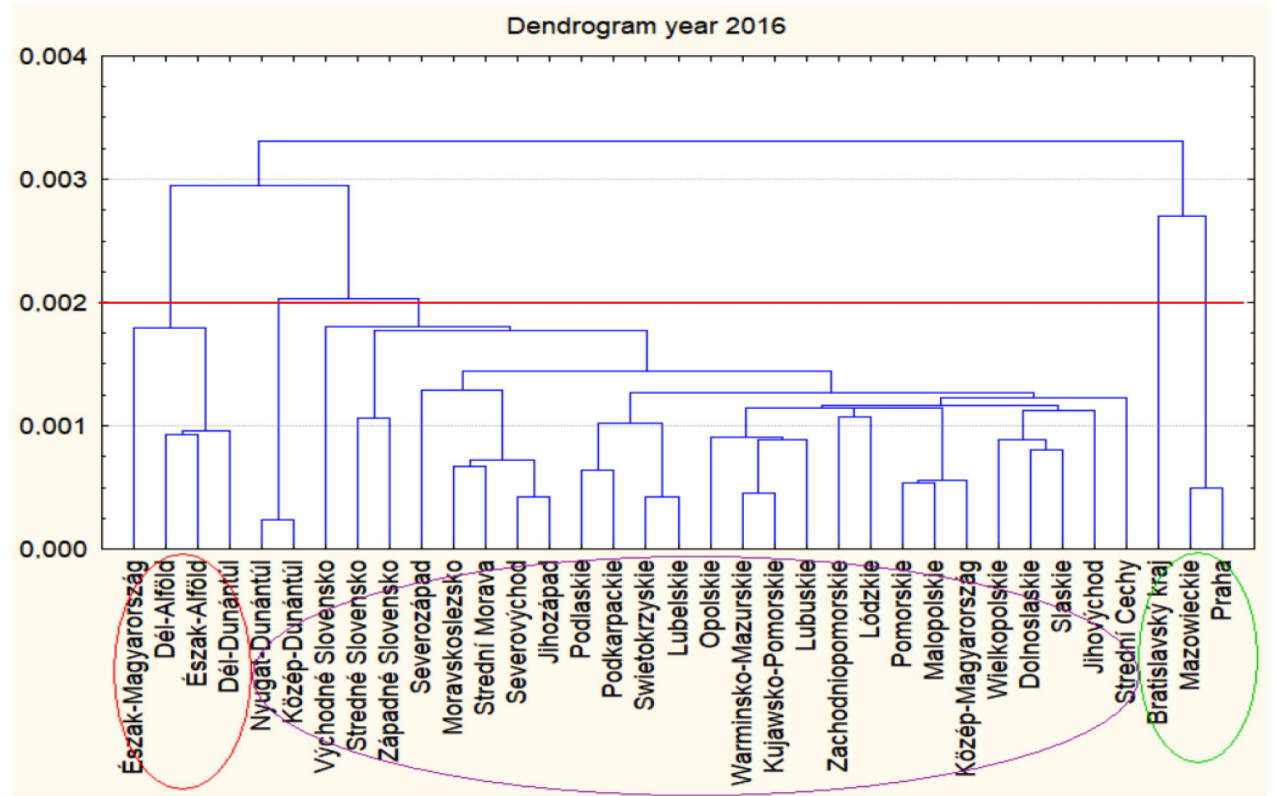

Figure 3. Dendrogram - year 2016 
The second main cluster contains two sub-clusters. The first contains the Hungarian regions only: Dél-Dunántúl, Észak-Magyarország, Észak-Alföld and Dél-Alföld. These regions share a relatively high average age (41 to 43.8 years), the lowest incomes, lower proportion of the population with tertiary education, lower employment rates and higher level long-term unemployment rates (from $2.5 \%$ to $4.00 \%$ ).

The remaining 28 regions are placed in the second cluster. Thus, improvements were recorded mainly in the factors of household income, employment, tertiary education, and infant mortality. The positive development of almost all factors was reflected in the increase of fertility rate (primarily in the Czech regions of Strední Čechy, Severovýchod, Severozápad, Jihovýchod, Jihozápad, but also in the Slovak region of Východné Slovensko, and the Polish region of Pomorskie). The Euclidean distance between the clusters was slightly larger.

The cluster analysis results are summarized in Figure 4.

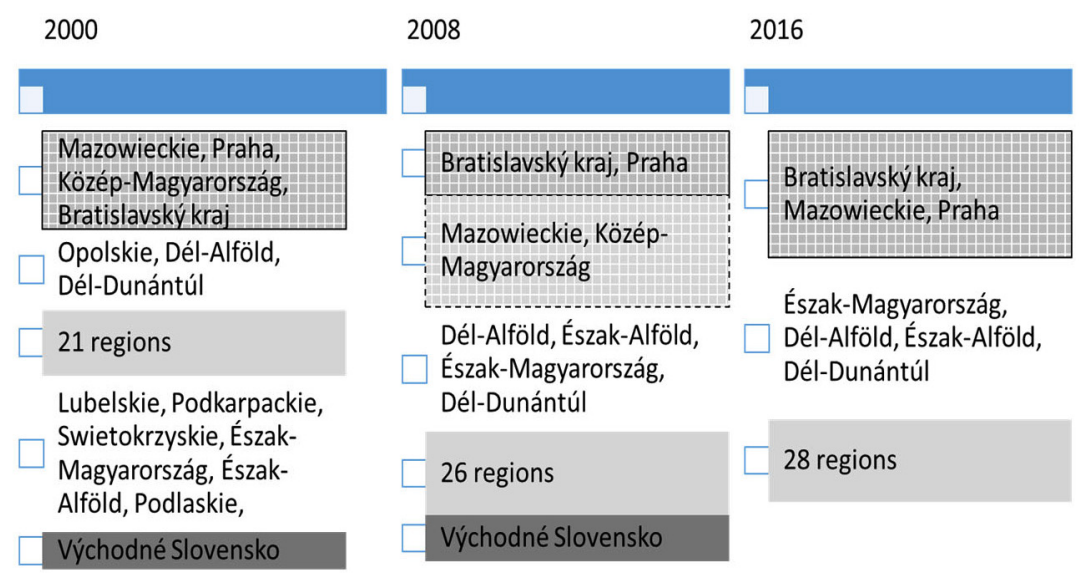

Figure 4. Summary (comparison) of the cluster analysis results

The results of cluster analysis for the years 2000, 2008 and 2016 and their comparison suggest that the Slovak region of Bratislava and the Czech region of Praha achieved the best results in all the years under analysis. The worst situation was found to be in the region of Východné Slovensko. In 2008, however, there were as many as 26 regions in the big group of regions compared to 28 regions in 2016 (seven more regions than in 2000).

\subsection{Assessment of differences in the indicators under examination in the V4 regions}

The variability of each factor examined was also looked at in a detail: minimum and maximum values, variation range (Figure 5) and variation coefficient (Figure 6).

The graphs in Figure 5 show that the biggest differences in 2000 between the maximum and minimum value were recorded in long-term unemployment and infant mortality rate, which, however, decreased slightly by 2016. In all three years under examination, the low differences between the maximum and minimum value were in median age and age dependency ratio. The tertiary education and income went up in all three years under examination, and so increased the differences between the maximum and minimum value in 2016 due to the income growth in the region of Bratislava. 


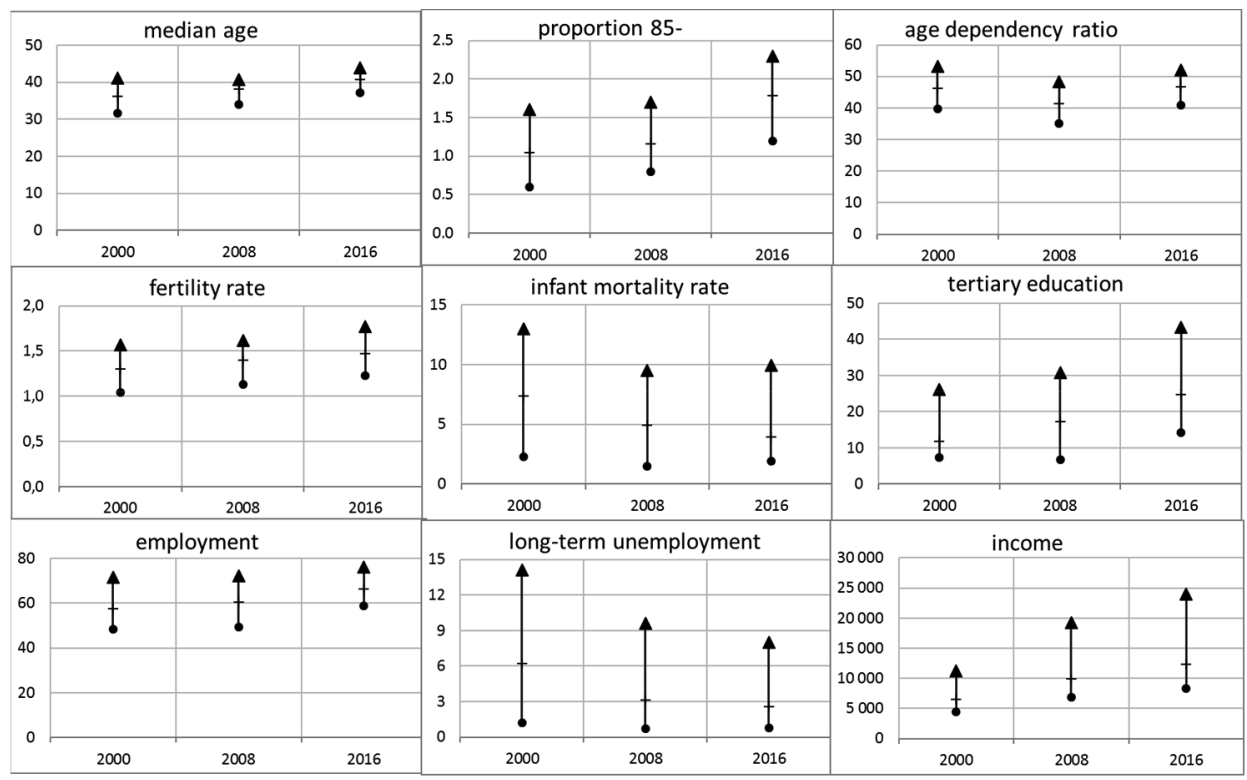

Figure 5. Development of absolute differences in the indicators examined (\%)

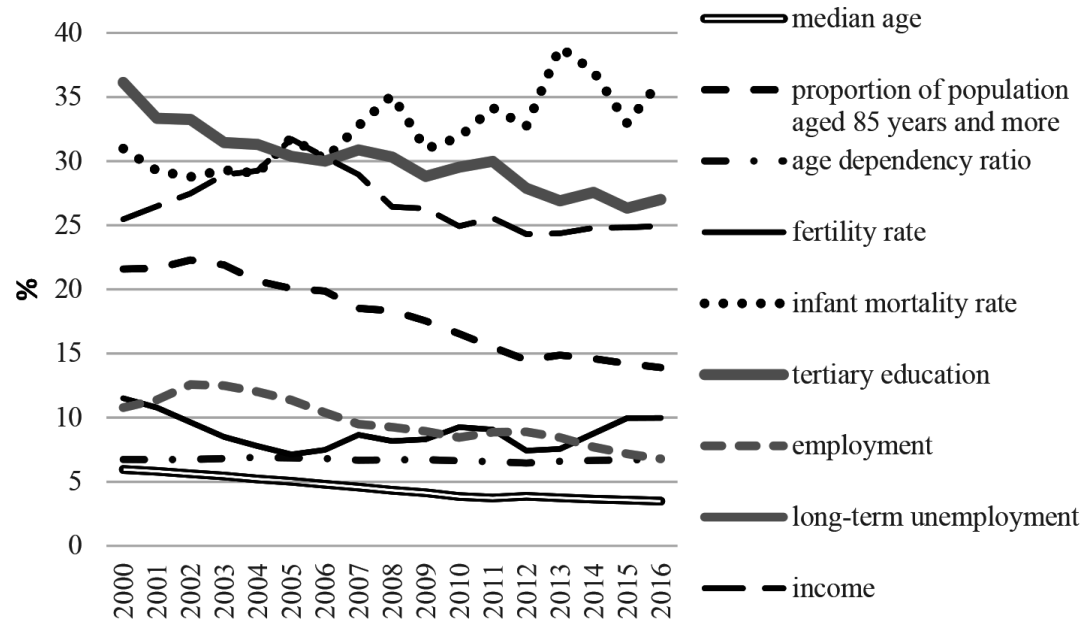

Figure 6. Development of the coefficient of variation in the indicators under examination (\%)

The development of the coefficient of variation shows that the differences are getting smaller in most of the indicators, except for two important demographic factors - infant mortality (a significant gap of the region of Východné Slovensko and the other regions) and fertility (lower values are reached in the Polish regions whereas the remaining regions experienced an increase in fertility), and age dependency ratio is almost left unchanged. 


\subsection{Summary of results and suggestions}

Based upon cluster analysis we could identify group of regions in the V4 countries from the perspective of the nine selected indicators determining human resources potential. In order to better compare and identify differences, we performed analysis in three selected years what enabled us to observe development of the changes within the clusters for a more years and to place the particular region (regions) into the particular cluster respectively to change and move particular regions among particular clusters. This approach enables to take into consideration, when analysing interregional differences, also specificity of more regions which belong to the particular group and it is possible to expect similar causes and problems in human resources potential development lagging. Therefore, based upon the results of the cluster analysis evaluation we can recommend the group of measures which could be the most relevant for the use of particular groups of the regions and which could contribute to its sustainable development and decrease regional disparities.

In the context of the research study, it can be concluded that education is given much more attention. In addition, there have also been provided optimum conditions for inclusive growth in the V4 countries. In the process of creating favourable conditions for inclusive growth, it is necessary to focus mainly on policies promoting equal access to education for persons with disabilities and marginalized groups. This is the area in which the Slovak regions (except for the region of Bratislava) and the Polish regions are not performing that well. The problem is mainly the little interest of citizens in education and training. Under the discussion, we suggest that the decision makers identify and differentiate entry conditions for learners' progress and determine the process adaptation and procedures for creating conditions for marginalized groups of students more precisely. In addition, the V4 policies should focus on the qualifications of those involved in teaching processes at all levels of education and create a more favourable climate and conditions for education, including the provision of teaching and learning equipment. It is also important to make the teaching profession more attractive and promising for the young generation. It does not only refer to higher educational attainments, but also to improved teaching and learning quality.

The quality of education has a strong link to the labour market through the indicators of unemployment rate, employment rate, labour cost, or household income. In this context, the decision makers should help the business environment as much as possible to attract the right people for jobs, i.e. to attract well qualified people in sufficient numbers. The findings related to the employment variability measurements in the V4 regions indicate that the relative differences in employment rates grew smaller: the differences were the biggest in 2002 and the smallest in 2016. From the regional perspective, the highest employment rates from 2000 to 2016 were found to be in the regions around the Czech (the region of Praha) and Slovak (the region of Bratislava) capital cities. The employment rates in the Polish region of Mazowieckie and the Hungarian regions of Közép-Magyarország and Nyugat-Dunántúl were fairly high. Much lower employment rates were found in most Hungarian, Polish and Slovak (primarily the region of Východné Slovensko) regions. When creating the conditions for well-functioning labour markets, decision-makers should realize that entrepreneurs cannot change the legislation and policies related to their business environment. Decision makers 
are not able to solve the labour market problems without considering the interests of entrepreneurs. Thus, it is necessary to strengthen for instance the power of local business chambers and entrepreneurial associations, and also to increase their engagement in tackling the problems and meeting the needs of local entrepreneurs. Business environment does not have a big impact on political decisions, yet there is room for a dialogue between entrepreneurs and decision makers or public sector in general. As the rate of economic growth is going up in the V4 countries, some sectors are facing labour shortages that put upward pressure on wages. Therefore, household income was looked at in the research study. The results indicate that there are profound differences in household incomes in the regions of the V4 countries. Generally, the highest household incomes are in the Czech Republic and Slovak Republic. From the regional perspective, the highest incomes per capita were in the region of Praha in 2000-2006. Subsequently, the highest incomes were in the region of Bratislava reaching $€$ 24,000 per year in 2016 ( $€ 19,500$ in the region of Praha in 2016). Far behind are the regions of Mazowieckie and Střední Čechy. The lowest income regions are the regions of Východné Slovensko, Podkarpackie from 2003, Észak-Alföld in 2011 and Észak-Magyarország in the following years. In 2000, the household incomes in the V4 regions ranged from $€ 4,400$ (Észak-Alföld) to $€ 11,200$ (Praha), in 2016 from $€ 8,300$ (Észak-Magyarország) to $€ 24,000$ per year (the region of Bratislava). Decision makers should be careful when it comes to income increase. Moreover, they should also encourage employers to give priority to hiring domestic labour. Foreign labour can contribute to economic growth now and in the years to come, but they should only help to fill job where there are shortages of workers. Otherwise, foreign labour may increase competition for existing jobs and employers may have an opportunity to suppress wage growth. Therefore, decision makers and active labour market measures should, in the first place, focus on identifying and addressing additional barriers that job seekers face.

It is not an easy task to examine the impact of social and demographic factors on regional development in terms of human resources due to nonconsolidated database and the choice of factors to be examined. The limitations of the study lie in the missing data, so the scope of factors under examination was constrained. Nevertheless, follow-up research activities can deepen and broaden the analysis of existing indicators by further relevant factors, and thus to deepen the existing knowledge on how the human resources potential contributes to the effective regional growth.

\section{Conclusions}

The perception of human resources in terms of regional development is one of the basic priorities not only in the Regional Development Strategy of the Czech Republic (Ministerstvo pro místní rozvoj ČR, 2013), but also in the other three V4 countries. The importance of individual factors for regional development stems from the nature of human resources, which are an active player in further development and this makes them distinct from other factors of a passive nature. Human resources are able to transform other resources or are essential for their functioning (Národná stratégia regionálneho rozvoja Slovenskej republiky, 2010). Human resources and their potential for development are determined by social and demo- 
graphic factors. Therefore, demographic trends currently affect by a large number of qualified policy decisions in the areas of economics, social affairs, employment and education. The demographic profile of countries and regions is influenced by the past population trends, yet it is also one determining the future development and further development potential of territorial units and societies

The aim of this research was to evaluate human resources potential with which V4 countries dispose and to identify group of regions which are the most similar from the social-demographic perspective. In order to identify the group of regions, we used hierarchical cluster analysis which enabled us to identify the regions with the comparable results of the selected indicators, which are connected with the potential of the human resources. We performed analysis in three selected years $(2000,2008,2016)$ which enabled us to observe changes in the development of the clusters in the particular regions. The regions were grouped based upon nine selected indicators connected with social and demographic human resources potential: median age of population, proportion of population aged 85 years and more, age dependency ratio, fertility rate, infant mortality rate, tertiary education, long-term unemployment rate, income and employment.

The results of cluster analysis confirm that the best conditions for the potential of human resources are concentrated mainly in metropolitan areas (the Slovak region of Bratislava, the Czech region of Praha, the Hungarian region of Közép-Magyarország and the Polish region of Mazowieckie). The distribution of human resources in these regions is given by the longtime process of their economic development. Their economic development is attractive for highly-qualified workforce that can make use of their potential in high-paying jobs. However, these regions are at risk of depleting available human resources and their potential. In addition, these regions are threatened by low fertility rate, especially in the region of Praha, high age dependency ratio and population aging (proportion of population aged 85 years and more). Metropolitan regions are the natural drivers of the economy of a given state due to their massive urbanization, and consequently the great concentration of human resources.

On the other hand, there are regions that do not make sufficient use of their potential in the area of human resources development. The lowest values were recorded in the region of Východné Slovensko, Czech regions of Moravskoslezský, Severozápad, the Hungarian regions of Észak-Alföld, Észak-Magyarország, Dél-Alföld and the Polish regions of Swietokrzyskie, Podkarpackie and Opolskie. These regions have to overcome economic and structural problems. The most critical situation is in the region of Východné Slovensko, which is struggling with long-term unemployment, high infant mortality and low incomes. As already mentioned, this is a problematic region that really needs effective regional policy instruments. The region, however, has a strong potential in terms of fertility rate, average age and tertiary education. These are the factors creating conditions for the human resources development in the region. From the geographical point of view, it is known that poor regions are much more likely to escape the poverty trap if they are surrounded by rich regions.

In order to stop adverse processes in the lagging regions, there must be more job opportunities. Regarding human resources, the quality of education plays an important role. Highly skilled and educated people are more adaptable to changes and better paid in the labour market. Removing shortcomings and low human resources potential in low-performing regions is the mission of public administration and decision makers. 
Even though the research was done early 2019, the research findings can be of use for researchers investigating the issue of regional development and regional disparities. In the research, relevant information and results are provided on which further work, not only in terms of demographic and social changes, can be build.

\section{Limitations and future research}

The work has some limitations which are mainly connected to the data drawn from Eurostat databases. Some indicator data were not available for certain years, and thus the most recent data could not be worked with. With regard to national statistical data, they are not compatible and difficult to obtain. This makes the use of national statistical data complicated.

Social, demographic and economic profile of countries and regions provide ample opportunities to research additional issues related to human resources development. In the future, it is intended to extend the existing research to other EU countries and to monitor the changes brought about by digitalisation. Additionally, the need for further education which would be instrumental in regional development and reduction of disparities is also intended to be examined. Last but not least, the effects of the aforementioned on the development potential of the regions in the EU should be investigated.

\section{Funding}

This work was supported by the Scientific Grant Agency of Ministry of Education, Science, Research and Sport of the Slovak Republic under Grant VEGA 1/0689/20.

\section{Author contributions}

Eva Koišová and Jana Masárová prepared the literature review, data collection, methodology and conclusions. Eva Koišová, Jana Masárová and Eva Ivanová elaborated chapters Introduction, Results and discussion and Conclusions.

\section{Disclosure statement}

Authors declare that they do not have any competing financial, professional, or personal interests from other parties.

\section{References}

Akócsi, I. L., Bencze, S., \& Tóth, T. (2012). New determination of human development at regional level in the countries of Visegrad. http://old.e-studies.ujs.sk/hu/cimlap/doc_download/8-201202.html

Arcalean, C., Glomm, G., \& Schiopu, I. (2012). Growth effects of spatial redistribution policies. Journal of Economic Dynamics and Control, 36(7), 988-1008. https://doi.org/10.1016/j.jedc.2012.01.004

Astafurova, O., Kulagina, I., \& Zapryagaylo, V. (2019). Transformation of the human resources regional market under the influence of economy digitalization. In Proceedings of the $2^{\text {nd }}$ International 
Scientific Conference on New Industrialization: Global, National, Regional Dimension (SICNI 2018) (pp. 655-660). https://doi.org/10.2991/sicni-18.2019.132

Bakó, T., \& Lakatos, J. (2016). The Hungarian labour market in 2015. In Zs. Blaskó \& K. Fazekas (Eds.), The Hungarian labour market 2016 (pp. 15-32). Institute of Economics, Centre for Economic and Regional Studies, Hungarian Academy of Sciences.

Bezák, A. (2001). O regionálnych trhoch práce, nových krajoch a tokoch nezamestnaných. Geografický časopis, 53(4), 295-305. https://www.sav.sk/journals/uploads/05131143Bezak.pdf

Bieszk-Stolorz, B., \& Dmytrów, K. (2020). Influence of accession of the Visegrad Group countries to the EU on the situation in their labour markets. Sustainability, 12(16), 6694. https://doi.org/10.3390/su12166694

Blažej, A. (2004). Quality of life from aspect of sustainable development in $21^{\text {th }}$ century. In Kvalita života a rovnost príležitostí - z aspektu vzdelávania dospelých a sociálnej práce (pp. 21-26). https://www.unipo.sk/public/media/29887/zbornik_z_vedeckej_konferencie.pdf

Bobáková, V. (2018). Význam ludského kapitálu a vzdelania pre ekonomický rast. Verejná správa a spoločnost', 19(1), 60-75. http://www.vsas.fvs.upjs.sk/files/62_vsas_2017_02-asopis-1_2018_final.pdf

Bolińska, M., Dykas, P., Mentel, G., \& Misiak, T. (2019). Emographic forecasts and volatility of investment rates Vs. labor productivity trajectories. Journal of Business Economics and Management, 20(6), 1045-1063. https://doi.org/10.3846/jbem.2019.10446

Chaaben, N., \& Mansouri, F. (2017, May 24-27). Digital economic and social evolution of Tunisia. In MIC 2017 - Management International Conference (pp. 393-404), Venice, Italy.

Chinoracký, R., \& Čorejová, T. (2019). Impact of digital technologies on labor market and the transport sector. Transportation Research Procedia, 40, 994-1001. https://doi.org/10.1016/j.trpro.2019.07.139

Del Campo, C., Monteiro, C. M. F., \& Soares, J. O. (2008). The European regional policy and the socioeconomic diversity of European regions: A multivariate analysis. European Journal of Operational Research, 187(2), 600-612. https://doi.org/10.1016/j.ejor.2007.03.024

Diebolt, C., \& Hippe, R. (2019). The long-run impact of human capital on innovation and economic development in the regions of Europe. Applied Economics, 51(5), 542-563. https://doi.org/10.1080/00036846.2018.1495820

Duszczyk, M., \& Matuszczyk, K. (2018). The employment of foreigners in Poland and the labour market situation. Central and Eastern European Migration Review, 7(2), 53-68.

EUROSTAT. (2018). Database. https://ec.europa.eu/eurostat/data/database

Fazekas, K., \& Köllõ, J. (2017). The Hungarian Labour Market 2017. Institute of Economics, Centre for Economic and Regional Studies, Hungarian Academy of Sciences. https://www.mtakti.hu/wp-content/uploads/2018/06/Contents.pdf

Gennaioli, N., La Porta, R., Lopez-de-Silanes, F., \& Shleifer, A. (2013). Human capital and regional development. The Quarterly Journal of Economics, 128(1), 105-164. https://doi.org/10.1093/qje/qjs050

Grmanová, E., Kostrová, J., \& Škrovánková, K. (2018). Demografické zmeny a ich vplyv na trh práce. TnUAD, Trenčín, Slovakia.

Habánik, J., Grenčíková, A., \& Krajčo, K. (2019). The impact of new technology on sustainable development. Inzinerine Ekonomika-Engineering Economics, 30(1), 41-49. https://doi.org/10.5755/j01.ee.30.1.20776

Hahn, J. (2013). The Visegrád Group - Growth Engine of Europe. https://ec.europa.eu/regional_policy/upload/documents/Commissioner/Speech-Visegrad-4-Ministerial-meeting-on-Cohesion_24062014. pdf

Hamada, R., \& Kasagranda, A. (2014). Selected economic, demographic indicators, indicators of infrastructure facilities and educational level of the population for the measurement of regional disparities. Regionální rozvoj mezi teorií a praxí, 3(1), 29-48. 
Havierniková, K., \& Janský, B. (2014). The evolution of regional disparities in the Slovak Republic. Vadyba, 25(2), 133-138.

Havierniková, K., Frankowska, M., \& Rafajová, L. (2018). The comparison of clustering issues between Slovakia and Poland. Ad Alta Journal of Interdisciplinary Research, 8(2), 79-84.

Hübelová, D. (2014, June 18-20). Evaluation of human resources in demo-geographical context cluster analysis of the districts of the Czech Republic. In Sborník príspěvkì XVII. mezinárodní kolokvium o regionálních vědách (pp. 224-230). Hustopeče. https://doi.org/10.5817/CZ.MUNI.P210-6840-2014-27

Ivanova, T., \& Zaretsky, A. (2019). Increasing role of human capital and evolution of values in digital economy. In IOP Conference Series: Materials Science and Engineering, 497, 012075. https://doi.org/10.1088/1757-899X/497/1/012075

Karamessini, M. (2008). Continuity and change in the southern European social model. International Labor Review, 147(1), 43-70. https://doi.org/10.1111/j.1564-913X.2008.00023.x

Kasanická, K., \& Czaková, G. (2009). Dynamika obyvatel'stva v mikroregióne Požitavie - Širočina. Geografické štúdie, 13(1), 28-39. https://doi.org/10.17846/GS.2009.13.1.28-39

Klimko, R. (2015). Labour market developments in Visegrad countries. International Journal of Social Sciences, IV(4), 16-29. https://doi.org/10.20472/SS2015.4.4.002

Klus, A. (2015). What makes the Visegrad Group so geopolitically fragile? New Eastern Europe. http://neweasterneurope.eu/old_site/articles-and-commentary/1617-what-makes-the-visegradgroup-so-geopolitically-fragile

Kostrová, J. (2018, April). Zamestnanost' starších obyvatelov na trhu práce v krajinách V4. In Scientia Iuventa 2018: Zborník príspevkov z medzinárodnej doktorandskej konferencie. Belianum, Banská Bystrica, Slovakia.

Kotýnková, M., \& Kubelková, K. (2012). Dopady hospodářské recese na český trh práce a výdaje na sociální dávky pro nezaměstnané. Auspicia, 8(1), 78-81.

Kožiak, R., Suchý, M., Kaščáková, A., \& Nedelová, G. (2014, June 18-20). Use of cluster analysis in the investigation of regional disparities. In Sborník príspěvkủ XVII. mezinárodní kolokvium o regionálních vědách. Hustopeče. https://doi.org/10.5817/CZ.MUNI.P210-6840-2014-3_

Kuźnar, A. (2018, September). The role of global value chains in deepening of economic linkages between Visegrad Group [Conference presentation]. 20 ${ }^{\text {th }}$ Annual Conference of European Trade Study Group (ETSG). Warsaw.

Laboutková, Š., Bednářová, P., \& Hovorková Valentová, V. (2016). Economic inequalities and the level of decentralization in European countries: Cluster analysis. Comparative Economic Research, 19(4), 27-46. https://doi.org/10.1515/cer-2016-0028

Larsson, A., \& Teigland, R. (2020). The digital transformation of labor. Automation, the Gig Economy and Welfare ( $1^{\text {st }}$ ed.). Routledge. https://doi.org/10.4324/9780429317866

Lelek, T. (2014). Trend analysis of human resources development representing the base for researchers in selected economies. Journal of Competitiveness, 6(1), 71-86. https://doi.org/10.7441/joc.2014.01.05

Lewandowski, P., \& Magda, I. (2018). The labor market in Poland, 2000-2016. IZA World of Labor, 426. https://doi.org/10.15185/izawol.426

Liptáková, K. (2007). Ludský potenciál ako jeden z faktorov regionálneho rozvoja. In $2^{\text {nd }}$ Central European Conference in Regional Science - CERS, 2007 (pp. 609-613). Technical University of Košice, Faculty of Economics. https://www.researchgate.net/profile/Katarina_Liptakova2/publication/242629259_ Ludsk_potencial_ako_jeden_z_faktorov_regionalneho_rozvoja/links/5e96e311299bf130799af16a/ Ludsk-potencial-ako-jeden-z-faktorov-regionalneho-rozvoja.pdf

Lv, J., Liu, Q., Ren, Y, Gong, T., Wang, S., \& Li, L. (2011). Socio-demographic association of multiple modifiable lifestyle risk factors and their clustering in a representative urban population of adults: A 
cross-sectional study in Hangzhou, China. International Journal of Behavioral Nutrition and Physical Activity, 8, 40. https://doi.org/10.1186/1479-5868-8-40_

Majerová, I. (2019). Socio-economic development and its impact on health personnel in regions of Visegrad Group Plus countries. Review of Economic Perspectives - Národohospodářský obzor, 19(1), 3-24. https://doi.org/10.2478/revecp-2019-0001_

Mariš, M. (2014). Regional disparities in the V4 countries. Regionální rozvoj mezi teórií a praxí. 2014(1), $52-65$.

Martinák, D. (2020). Vplyv technologického pokroku na štruktúru zamestnanosti v krajinách V4. Politická ekonomie, 68(1), 42-61. https://doi.org/10.18267/j.polek.1265

Mayerová, K., \& Hyžová, S. (2019). Development of information technologies and their impact on the labor markets. Sociálno-Ekonomická Revue (Social and Economic Revue), 17(2), 70-79.

Mihalčová, B., Pružinský, M., Janíčková, J., Olexová, C., Pružinská, J., \& Gavurová, B. (2007). Riadenie ludských zdrojov. Ekonom Publishing Company in Bratislava.

Minařík, B., Borůvková, J., \& Vystrčil, M. (2013). Analysis of regional development. Professional Publishing.

Ministerstvo pro místní rozvoj ČR. (2013). Strategie regionálního rozvoje ČR 2014-2020. https://mmr.cz/ cs/Ministerstvo/Regionalni-rozvoj/Regionalni-politika/Koncepce-Strategie/Strategie-regionalnihorozvoje-CR-2014-2020-(1)

Národná stratégia regionálneho rozvoja Slovenskej republiky. (2010). http://www.mpsr.sk/mvrrfiles/003994a.pdf

Naydenov, K. (2019). Human resources development as a factor for regional development. In $19^{\text {th }}$ International Multidisciplinary Scientific GeoConference: SGEM 2019 (Vol. 19, pp. 475-482). Sofia. https://doi.org/10.5593/sgem2019/5.4/S23.063

Novikov, V., Klochko, E., Brizhak, O., \& Digtyar, O. (2020). Digital economy: Human capital, technology, communications. In Proceedings of the $5^{\text {th }}$ International Conference on Economics, Management, Law and Education (EMLE 2019) (pp. 198-204). https://doi.org/10.2991/aebmr.k.191225.035

Palevičienè, A., \& Dumčiuvienè, D. (2015). Socio-economic diversity of European regions: Finding the impact for regional performance. Procedia Economics and Finance, 23, 1096-1101. https://doi.org/10.1016/S2212-5671(15)00431-1

Potužáková, Z. (2012). Trhy práce ve státech Visegrádské čtyřky a ekonomická krize. Acta Oeconomica Pragensia, 20(1), 13-24. https://doi.org/10.18267/j.aop.355

Rajčáková, E., \& Divinský, B. (1995). Analýza nezamestnanosti Rómov na Slovensku vo vztahu k štruktúre obyvatel'stva. Geographia Slovaca, 10, 231-239.

Řezanková, H., Húsek, D., \& Snášel, V. (2007). Shluková analýza dat. Professional Publishing.

Sahadev, S., \& Demirbag, M. (2011). Exploring variations in employment practices in the emerging economies of Europe: Assessing the impact of foreign ownership and European integration. Human Resource Management Journal, 21(4), 395-414. https://doi.org/10.1111/j.1748-8583.2011.00183.x

Shubat, O., Bagirova, A., \& Šmarová, I. (2017). The use of cluster analysis to assess the demographic potential of Russian regions. In Proceedings $31^{\text {st }}$ European Conference on Modelling and Simulation (pp. 53-59). Budapest, Hungary. https://doi.org/10.7148/2017-0053_

Stankovičová, I., \& Vojtková, M. (2007). Viacrozmerné štatistické metódy s aplikáciami. Bratislava, Iura Edition.

Székely, V. (2001). Časovo-priestorová diferenciácia nezamestnanosti a jej tokov na Slovensku v rokoch 1997-1999. Geografický časopis, 53(2), 147-170.

Tchanturia, N., Beridze, T., \& Kurashvili, G. (2015). Features of development of the human capital in Georgia. Procedia - Social and Behavioral Sciences, 213, 580-585.

https://doi.org/10.1016/j.sbspro.2015.11.453 
Tuleja, P., Majerová, I., \& Nezval, P. (2006). Základy makroekonomie (1 vyd.). Computer Press.

Ulewicz, R., \& Blašková, M. (2018) Sustainable development and knowledge management from the stakeholders' point of view. Polish Journal of Management Studies, 18(2), 363-374. https://doi.org/10.17512/pjms.2018.18.2.29

Valuch, J., Rišová, M., \& Seman, R. (2011). Právo medzinárodných organizácií. C. H. Beck.

Vasilescu, M. D., Serban, A. C., Dimian, G. C., Aceleanu, M. I., \& Picatoste, X. (2020). Digital divide, skills and perceptions on digitalisation in the European Union - Towards a smart labour market. PLoS ONE, 15(4), e0232032. https://doi.org/10.1371/journal.pone.0232032

Vilinová, K., \& Repaská, G. (2018). Dynamics of selected demographic indicators of population in the hinterland of the Nitra City. In V. Klímová \& V. Žitek (Eds.), $21^{\text {st }}$ International Colloquium on Regional Sciences. Conference Proceedings (pp. 722-729). Masarykova univerzita. https://doi.org/10.5817/CZ.MUNI.P210-8970-2018-95_

Visegrad Group. (2016). About the Visegrad Group. http://www.visegradgroup.eu/about

Vojtovic, S., \& Krajnakova, E. (2013). Trends in economic growth and unemployment in Slovakia. In Proceedings of the 2013 International Conference on Education, Management and Social Science (ICEMSS-13) (pp. 188-191). Atlantis Press. https://doi.org/10.2991/icemss.2013.51_

Zhang, X., \& Li, Z. (2014). Application of cluster analysis to western China population quality assessment. In EEE-2014: International Conference on E-Commerce, E-Business and E-Service (pp. 239242).

Zurn, P., Dal Poz, M. O., Stilwell, B., \& Adams, O. (2004). Imbalance in the health workforce. Human Resources for Health, 2, 13. https://doi.org/10.1186/1478-4491-2-13 